fossils, very few phosphatic nodules, and very little iron oxide. This seems to show that Walton was within the influence of a warm ourrent as to temperature (as shown by its species), but from some local cause escaped its eroding action (as shown by the conditions of deposition), and consequently did not receive the foreign bodies which would have required a swift stream to import.

Hariton, Near Cambridae.

O. Fisher.

\title{
ELEPHAS MERIDIONALIS IN THE RED CRAG.
}

Sir,-Mr. Lankester, in your last number, inquires " What grounds have the Rev. John Gunn and the Rev. O. Fisher for stating that the $\boldsymbol{E}$. meridionalis is found in the Red Crag?" I reply that I saw a specimen-an old much water-worn molar-in the collection of Mr. J. H. Roper, of Lowestoff, Suffolk, merchant. It appeared to have been derived from an older, or basal portion of the Red Crag; and, if so, the $E$. meridionalis is referred back to at least the commencement of that crag, which admits, I believe, of several subdivisions. I quite agree with Mr Lankester that there is " no reason for believing that the specimen of $E$. antiquus mentioned in Palæont. Mon. Vol. II., p. 181, was derived from the Red Crag. Dr. Falconer says that it came from Southwold, where there is no Red Crag at all. A ridge of Coralline Crag at Aldburgh appears to separate the Red from the White Norwich Crag, and there is, as Mr. Prestwich maintains, no instance of superposition of those two crags. I may safely affirm that no specimens of the Rhinoceros Schleiermacheri, or Hipparion, have been found in Norfolk. Mr. R. Fitch has, I think, some of the Hyoena antiqua (?) The Ursus arvernensis (so named by $\mathbf{M}$. Lartet) abounds in the Forest-bed, and also the Rhinoceros Etruscus. Having noticed the points of reference made to me, I might conclude; but on looking to the next page, I observe that Mr. Fisher is exposed to a raking fire from Colonel Greenwood. As I know that my friend is quite equal to self-defence, I will not further interfere in the fray than to ask how, if the erosion of the valley at Lopham be attributable to either pluvial or fluvial denudation, supposing the water-shed to have been ever on that spot, could the magnificent bed of valley gravel have been deposited on the bank near the ford and the watershed. I should be glad to be instructed on this point. In a paper, which I read at the British Association at Norwich, I attributed the formation of the water-shed to an upheaval, which may be traced through Norfolk, and which brought the Chalk to the surface at Trimmingham, after it had dipped beneath the beach at Cromer. The river, I conceive, previous to that upheaval, had flowed to the east or to the west, and had deposited that valley gravel. - How it came there under either Colonel Greenwood's or Mr. Fisher's hypothesis, I do not understand. I suppose that snow-falls are taken into account under pluvial action. The power of these during the Reindeer period must have been very great.- I am, etc.,

IRSTEAd RECTORY, Jan. 19, 1869.

JoHN GONN. 